\title{
ResearchOnline@JCU
}

This is the author-created version of the following work:

Bruce, Christine (2001) Faculty-librarian partnerships in Australian higher education: critical dimensions. Reference Services Review, 29 (2) pp. 106-115.

Access to this file is available from:

https://researchonline.jcu.edu.au/55529/

Copyright (C) MCB University Press

Please refer to the original source for the final version of this work:

https://doi.org/10.1108/00907320110394146 
FACULTY- LIBRARIAN PARTNERSHIPS IN AUSTRALIAN HIGHER EDUCATION

Christine Bruce

Associate Director, Information Systems Management Research Centre

School of Information Systems

Queensland University of Technology

c.bruce@qut.edu.au

word count 6330 


\title{
FACULTY- LIBRARIAN PARTNERSHIPS IN AUSTRALIAN HIGHER EDUCATION
}

\begin{abstract}
Australian higher education is presently subject to a period of substantial change. The needs of the economy and workforce, together with the broader educational role of the university are leading to focus on lifelong learning as a tool for bringing together the apparently diverging needs of different groups. Within this broader context, the emphasis on lifelong learning and associated graduate capabilities is leading to opportunities for new partnerships between faculty and librarians, partnerships that bring the two groups together in ways that are helping to transform the experience of teaching and learning. This paper explores emerging partnerships in diverse areas, including research and scholarship, curriculum, policy, supervision, and staff development. They are in the early phases of development and result from a broad focus on the learning and information literacy needs of students, as opposed to a narrow focus on using the library and its information resources. Taken together, and viewed from a system-wide perspective, these partnerships reveal a complex dynamic that is deserving of wider attention across the Australian higher education system and internationally.
\end{abstract}

Keywords: information literacy, Australian higher education, policy, curriculum integration, academic development, research.

\section{The character of Australian higher education}

During the last ten years, Australian higher education has undergone a period of substantial and continuing change. Key developments have been the amalgamation of institutions leading to larger bodies; and the abolishment of the binary divide resulting in many Colleges of Advanced Education and Institutes of Technology joining with, or transforming themselves into, universities. Alongside the major changes associated with these developments, universities and their staff are contending with reduced funding from governments as well as increased emphases on flexible delivery, distance education and online teaching. Growing numbers of students are entering undergraduate programs, and growth is also being sought in the postgraduate market, now a full fee-paying clientele. In 1999 the Australian Higher Education ${ }^{\mathrm{i}}$ system comprised 686,202 students, of which 276, 343 (or 40\%) were commencing students; and 76,040 full time and fractional staff, of which 29, 748 were classified as academics. This data was obtained from the 41 higher education institutions that 
receive operating grants from the Federal Government, and a small number of other institutions (DETYA 1999a,b).

Higher degree programs, particularly for professional disciplines, target a mobile student population and often need to be delivered online to students travelling all over the world. Employer needs, student and professional association requirements, are driving course development more strongly; a trend that has led recently to serious investigation of US based and other corporate universities, with their emphases on market driven training programs (Cunningham et al, 2000). Within this general picture, issues of generic capabilities and graduate attributes have become central to the educational debate; including what such skills and attributes are, how they should be taught, and how they should be monitored or assessed.

A vision has been established of universities that provide for formal learning opportunities throughout life, as well as enabling students to become independent learners. Such visions coexist with discussion about the nature of graduate competence and the character of teaching and learning that should be supported. A foundational assumption is that the future for which we are educating our graduates is uncertain, and therefore, that the kinds of capabilities they need are those that will enable them to deal with an unknown future (Bowden and Marton, 1998). Based on these ideas, one grouping of universities, known as the Australian Technological Network has developed a very thorough statement on graduate attributes and how they may influence the university teaching culture. (Bowden et al, n.d.)

The idea of lifelong learning, and the centrality of information literacy to the lifelong learning agenda, has made various inroads into the policy and programs of Australian Universities. The important contribution of information literacy to the educational experience has been highlighted by the Employment and Skills Council report Education and Technology Convergence (Tinkler, Lepani and Mitchell, 1996); and by the National Board of Employment, Education and Training report Developing Lifelong Learners Through Undergraduate Education (Candy, Crebert and O’Leary, 1994). The latter report has had a significant influence of higher education policy development. Many universities are now seriously attending to lifelong learning as a 
graduate outcome, paving the way for faculty-librarian partnerships such as those discussed in this paper.

\section{The role of the university library in teaching and learning: establishing new partnerships}

Like their counterparts elsewhere in the world, Australian university libraries are recognising that their service role in the provision of information resources and services is insufficient. Integral involvement in the teaching and learning function of the university is becoming a strong imperative. While faculty-librarian partnership in the teaching-learning process is not a recent phenomenon for Australia, new emphases on information literacy and the role of the library in teaching and learning, have strengthened those partnerships, and even transformed their character. The shift, in a very few years, from introducing students and staff to information facilities, conducting 'one-shot' lectures, or developing workbooks for large groups of undergraduates to the kinds of partnerships described in this paper, has been remarkable. Many of these new partnerships have been led, at least initially, by librarians, with uptake and partners found in various parts of the university - learning support units, academic development units, computing centres, academic boards, as well as discipline based faculty.

Librarians that have established successful partnerships at a variety of levels, have discerned the critical features of the university agenda which enable them to contribute effectively. Some libraries have been able to use the broad interest in lifelong learning to work closely with faculty in raising the profile of information literacy and constructing a university-wide focus on information literacy as a key to student learning. Examples of such institutions are the University of Ballarat (Radomski, 2000), the Australian Catholic University, Central Queensland University (Appleton and Orr, 2000) and the University of South Australia (George et al, 2000). Other universities have used other hooks. The University of Queensland, for example, has established the need for information management skills for its graduates, and the University of Wollongong established the term 'information literacies' to encompass statistical literacy, information literacy and computer literacy. (Wright and McGurk, 2000). At Griffith University, Queensland University of Technology and elsewhere, 
the graduate attributes discourse includes an interest in the ability to access, evaluate and use information. In many institutions the emphasis on flexible delivery has enabled collaborative work on product development or curriculum design.

A growing appreciation of the importance and nature of information literacy and the need for contextualisation in specific insititutions and disciplines is discernible. As in the rest of the world, the agenda is characterised by a range of interpretations of information literacy (Bruce, 1997; Candy, 2000); each institution creates its own definitions and lists of attributes expected of graduates. Like the idea of information literacy, the idea of lifelong learning itself is subject to different interpretations, including fostering students' capacity for self-directed, independent enquiry (the emancipatory view) and making possible ongoing reskilling (the corporate view) through continuing education and postgraduate courses. Some courses, both undergraduate and postgraduate, are bringing these approaches together through the introduction of action learning, action research or problem-based learning components to the curriculum. Different nuances associated with the idea of lifelong learning therefore exist in different parts of the university community and librarians need to identify and work with these in order to be effective.

\section{Faculty-librarian partnerships: five critical dimensions}

Faculty-librarian partnerships that are slowly transforming student learning in Australian higher education seem to be based on changing views of the world from both librarian and faculty perspectives. Librarians are beginning to recognise the need to move away from a library and information retrieval centred view of information literacy towards a broader understanding of the role of information literacy and the information professional in fostering student learning. From a faculty perspective, there is a developing recognition of the importance of the world of information and information literacy to student learning. Nimon (2000, p.163), makes explicit for us the idea of a 'gap' between library-centred and academic ways of thinking about information literacy; a gap that needs to be bridged for student learning to be supported and transformed. As faculty and librarians work together, they are likely to develop shared understandings of how student learning can be supported. 
For the purposes of this paper, I have attempted to classify faculty-librarian partnerships by identifying critical differences in focus. The result is clearly not a true classification because some partnerships operate across more than one. The following five types of partnerships are, therefore, offered as a way of seeing work in progress: Policy partnerships, research partnerships, curriculum partnerships, higher degree supervision partnerships and academic development partnerships. In theory, I suspect, that each of these represents different dimensions of the faculty-librarian partnership dynamic, and that where more dimensions are represented, the dynamic is consequently stronger. The strongest partnerships, and the greatest impact of these partnerships is likely when all dimensions are working coherently together in the one institution or 'network'. In what follows, different dimensions of the partnership dynamic are represented by different institutions and programs. In some cases multiple dimensions are present in the same institution, but some dimensions are stronger than others.

Most of the material for this paper has been obtained from Australian publications on information literacy, recent conferences and a search of the Australian indexing services and the web. While some material has been obtained that is as yet unpublished, the paper does not represent a comprehensive picture of work being undertaken in Australia. The examples are representative of programs that for one reason or another have obtained a high profile in the Australian community. Readers may find it useful to note that, in Australia, librarians in universities mostly do not have faculty status.

\section{Policy partnerships}

The development of university policy is one area that is benefiting from librarianfaculty partnerships. Policy documents include such items as information literacy plans, lists of graduate attributes or 'qualities of graduates', and strategic plans such as teaching and learning plans. Librarians are working with faculty to bring the information needs of students into focus in the construction of such policy. Central Queensland University’s Teaching and Learning Management Plan, for example, outlines a 'commitment to information literacy and the need for lifelong learning 
skills to be incorporated into academic programs' (Appleton and Orr, 2000). There seem to be two possible approaches to policy development partnerships. In the first, librarians drive the development of, for example, information literacy policy, and consult with faculty during the process. In the second approach, librarians and faculty work collaboratively on policy development. The examples provided here are instances of the latter approach.

At the University of Wollongong and the Australian Catholic University, University Teaching and Learning Committees have provided a vehicle for the development of policy documents that emphasise the importance of student learning and the subsequent need for a curriculum focus on information and other literacies. These documents have been developed collaboratively by teams of librarians and faculty, and point towards far reaching change in curriculum design and implementation. (Australian Catholic University Information Literacy Committee 1999; Wright and McGurk, 2000; Milne and Peisley, 2000).

At the University of Ballarat, the information literacy policy is a university document designed to converge with Boyer's four scholarship (Radomski 1999); thus aligning closely with the direction of the university which is taking very seriously the implementation of those scholarships. The emergence of such a policy was made possible through the working relationships established between librarians and other members of the university community, particularly the interest taken by the Deputy Vice Chancellor (Scholarship) Professor Philip Candy, in information literacy. The University of Ballarat's policy documentation identifies information literacy as a 'key graduate outcome and as an integral part of an undergraduate curriculum model that places lifelong learning and generic/transferable capabilities at the heart of course curriculum design’ (Radomski, 2000).

\section{Research and scholarship partnerships}

Research and scholarship partnerships in Australia tend to be instances of faculty and librarians either working together on elements of the information literacy research 
agenda, or engaging collaboratively in scholarship associated with designing discipline-based learning experiences to foster information literacy.

Perhaps the most intensive example of faculty-librarian partnerships in Australia comes from the University of Ballarat, where program development has been fundamentally an exercise in research and scholarship. Natalie Radomski (a librarian, now appointed as an academic developer) has been instrumental in establishing an action research project, involving a number of different cases, to explore the issues and possibilities associated with making information literacy a central curriculum concern. Professor Philip Candy writes in a Foreword to the project's Final Report (Radomski, 1999), that the study 'demonstrates the university's commitment to Information Literacy as a major organising feature of its academic work', and represents ' .... an important educational innovation for which there are few precedents in Australia or elsewhere'. The project is unique in its university-wide adoption of a critical scholarly approach, by librarians and faculty in partnership, to redesigning curriculum within an information literacy framework.

Commencing in 1997, the project brought together academic staff, librarians and other members of the university community in taking a reflective and scholarly approach to the information literacy agenda. Four areas of teaching and learning were targeted, including undergraduate courses, research students and researchers, and bridging students. Each project had a far reaching aim, such as 'examining the changing role and contribution of information librarians within an emerging university-wide curriculum integrated information literacy model' (Radomski, p.77), or 'examining one teaching team's practice in problematising and critiquing how the phenomenon of information literacy might be understood and integrated'. (Radomski, p.60)

Research and scholarship are also fundamental to effective partnerships elsewhere. Evaluation appears to be a popular focus. At Central Queensland University during the mid-1990s, for example, librarians and faculty applied jointly for research funding. This brought the two groups together for the purpose of conducting research. Ongoing interest of both faculty and library staff in information literacy research and scholarship is a key outcome of this partnership. Faculty research that has grown out 
of the early partnerships at Central Queensland University include an examination of nursing students attitudes towards information literacy (Searl et al, 2000), and a statistical investigation of the relation model of information literacy (Catts, 2000). At the University of Wollongong, nursing faculty have also engaged in the evaluation of teaching information literacy skills (Wallace, Shorten and Crooks, 2000). Action research is being used at the University of Queensland to evaluate information literacy instruction in a first year engineering subject (Hill, 2000).

Another important focus for library faculty partnerships in this area are teaching and learning grants, which usually fund the development of new approaches for improving student learning. At the Queensland University of Technology, for example, library and faculty are working together on two major projects funded under such a scheme. The first, involving a Teaching and Learning Innovation Grant of AUS\$100,000, has librarians working with faculty members to evaluate their designs for embedding information literacy into curriculum. It also involves the development of workshops to assist faculty to design curriculum that will foster information literacy. The second, involving a Teaching and Learning Large Grant, has a librarian seconded to the Law Faculty to help staff embed generic skills and discipline specific attributes in curriculum (Peacock, 2000).

The seeds being sown by projects such as these are of considerable importance to the national agenda for information literacy and student centred learning in Australian higher education. Outcomes for both faculty and librarians will assist the ongoing development of the agenda. For both groups these outcomes may include an appreciation of the place of information literacy in student learning as well as the value of subjecting this to the rigours of scholarly reflection and research. Taking such an approach to information literacy education highlights the contribution of information literacy to student learning for the rest of the university community and often results in collaborative publication. For both faculty and librarians these projects have led to an ongoing interest in the area, opportunity for publication and contribution to the domains of information literacy education and research. 


\section{Higher degree supervision partnerships}

In higher degree supervision partnerships, faculty and librarians share responsibility for helping students through the phases of higher degree research. This is particularly important in the Australian context where research degrees are still pursued with limited coursework components.

A version of the three way partnership between student, supervisor(s) and librarians (Bailey, 1985) has been trialled at Deakin University. Following this trial, Macauley and Knight (1998) propose that librarians should adopt the role of co-supervisor, to ensure that literature reviews are relevant and complete, and to keep supervisors and students up to date with information resources and services. They argue that this approach would lead to several benefits, including more completions, more timely completions, higher quality research, better information literacy skills and improved research collections. The Macauley and Knight model is beginning to attract the interest of other universities. Maureen Nimon (2000), for example of the University of South Australia records her intention to shape a program for her research students based on elements of the Macauley and Knight model. One of the key challenges in this province is to ensure that students receive the wider benefits of working closely with an information professional; allowing them to both work independently in the information environment and receiving search and retrieval services that augment the students' work.

Information literacy coursework opportunities have been provided for research students since the late 1980s. These programs, which bring students together to work on progressing their research, have a substantial role to play in successful higher degree research outcomes. Australia's first major program in this area was a university wide, credit-bearing unit for honours, masters and $\mathrm{PhD}$ students (Bruce, 1989). That unit, Advanced Information Retrieval Skills (IFN100), was designed and implemented at the Queensland University of Technology in the late 1980s, where it continues to be taught for cross-disciplinary groups, or as part of discipline specific coursework. Coursework opportunities for research students have since been made available at many other universities. 
The Queensland University of Technology program, during its development, was conceptualised as a vehicle for assisting students in the preparation of their literature reviews or research proposals. Where staff implementing such programs see themselves as co-supervisors (advisors) with faculty, the approach to teaching and learning can take students beyond information retrieval, management and even evaluation. A focus on how the information sought is actually to be used can result in looking at ways in which students experience aspects of the research context and how they make use of the ideas encountered. Insights of significance to higher education student learning at the postgraduate level can result. For example, Bruce (1994, in press) presents outcomes from an investigation into students' varying ways of experiencing literature reviews, and Macauley (2000) provides an important discussion of the views of faculty and students on how information literacy skills could be acquired.

\section{Curriculum partnerships}

Curriculum partnerships are being developed in a wide variety of ways, and with many foci. Resulting curriculum design includes interventions positioned variously on spectrum between special subjects that teach information, technology and communication skills to significant change in design for learning of discipline based curriculum. Librarians are heavily involved in product development such as web sites for courses and subjects, as well as self-paced information literacy modules, increasingly web materials, that may be used by staff and students.

Librarians are also working closely with faculty on strategies and principles for designing learning. University of Queensland librarians report that, in 2000, members of the library staff and the University Teaching and Learning Committee will consider 'ways in which attributes such as critical analysis and problem solving can be fostered through the integration of information skills into curriculum'. (Turnbull, Frost and Croud, 2000). At the University of South Australia, recognition of lifelong learning as a graduate outcome has led to the development of a range of tools that use information literacy as one framework for the practical outworkings of the lifelong learning policy (George et al, 2000). The library’s strong involvement in the lifelong 
learning discourse has helped to create an environment that facilitates the required learning outcomes.

\section{Construction of special units and parallel programs}

The development of course units (for credit or 'zero credit') and other programs that foster information literacy, or a range of generic attributes including information literacy is a popular strategy, particularly as a means of reaching beginning undergraduates. Two different orientations to non credit bearing programs come from the University of Wollongong (Milne and Peisley, 2000) and Griffith University (Abbott and Peach, 2000).

The recently piloted Griffith Graduate Project adopts a student centred approach to improving learning across nine generic skill areas, including: self-management skills, interpersonal skills, problem-solving and decision-making, adaptability and learning skills, team work and information skills. Students are invited to rate their skill level, embark on a self-managed goal setting process for improving their skill levels and, over the period of their degree, develop a Professional Portfolio that includes generic skill elements. The inclusion of information skills in the generic attributes has led to important roles for librarians in the process; particularly in establishing dimensions of information literacy that should be assessed and the development of a resource directory that will support students in their development goals. (Abbott and Peach, 2000)

At the University of Wollongong entry level students complete a four hours of compulsory modules that has been named the Information Literacies Introductory Program (ILIP). This has been designed and convened by a team of staff from the library, Information Technology Services and the Centre for Educational Development and Interactive Resources. The program involves students in becoming familiar with the technology environment, in particular activating their computer account, completing a library based information literacy session either face to face or in a self-paced fashion, and completing and submitting an assignment via the web. This program has become a zero-credit unit, in which all commencing students are automatically enrolled. The modules may be completed at any time in the first year of 
study; some courses require early completion as other assignment tasks build on the learning achieved. Programs like this are intended to provide a universal level of basic skills which students then bring to their academic studies.

\section{Design of discipline curriculum}

While the redesign of curriculum within problem-based or resource-based learning frameworks for information literacy education continues to be advocated, as yet few examples have found their way into the literature. Nevertheless, useful models are beginning to emerge (Radomski, 1997; Appleton, Mc Pherson and Orr, 2000; Booker, 2000; Bruce and Candy, 2000a). Some of these models show the impact of librarians working in teams on the design of course-materials and implementation. At the University of Queensland, for example, engineering faculty have worked with library staff, higher education advisers and engineering consultants to develop appropriate curriculum for Introduction to Professional Engineering, catering for some 500 students. (Hill, 2000) Other partnerships reveal various forms of scaffolding of information literacy learning, and attempts to overcome the problem of content being side-lined. Nursing faculty and librarians at the University of Wollongong have designed a staged program of learning activities and assessment tasks that take students from the basic steps of understanding citations, to critically analysing articles as preparation for writing literature reviews (Brewer, 2000; Wallace et al 1999).

One substantial innovation representing the move towards resource based learning, for the purpose of bringing together content learning and information literacy development, comes from Leonie Hinton of Central Queensland University. Hinton (2000) describes a sequence of assessment items in a unique subject for health professionals taught by faculty-librarian partnerships. The three items each involve one of three important contexts for information literacy: everyday life, workplace and research. In the first piece of assessment 'students write a letter to an aged aunt who requested health information for a member of the family. Criteria and sample letter are given to students. The task requires the student to identify and search for appropriate information...students access a variety of sources both formal and informal... The second piece of assessment requires the student to be a health professional dealing with the relative with a health concern. The task is to prepare a 
portfolio of information, a letter to the relative about the use and navigation of such information, and a memorandum to the supervisor about why such information is included... The third item is a scholarly paper on an identified health concern applicable to the relative in the previous assessment. The task requires the students to write a paper similar to those submitted for publication... The best 30 papers submitted by students are edited and published by the school.' (p.190-1)

Libraries belonging to the Australian Technological Network grouping of universities are presently documenting their experiences of collaboration for publication. At the Queensland University of Technology, three partnerships have been selected for profiling in that work. Callan, Peacock, Poirier and Tweedale (in press) analyse the relationships between library and faculty in the Faculties of Information Technology, Built Environment and Engineering, and the Arts, where information literacy concepts and skills are being brought to large groups of first year students completing core units. Up to six-hundred students are targeted in each unit, with librarians participating in lectures, providing online tutorial support, assessment and evaluation. The units concerned largely focus on generic attributes including information, computer and academic literacy, ethics, and professionalism.

The different kinds of curriculum strategies reflect different values and philosophies of teaching and learning. Ultimately the aim for Australian librarians and faculty must be to help students learn content through the processes of information use. This will mean applying Biggs' (1999) principle of constructive alignment; and placing more emphasis on information literacy as a way of working with information that can be encouraged or discouraged by particular learning activities (Bruce and Candy, 2000b).

\section{Academic development partnerships}

In Australia, academic developer and librarian partnerships are an important vehicle for bringing the information needs of students to the attention of faculty. They also help promote the value of information literacy education. Most of this work is done through institutional academic development units, with the Higher Education Research and Development Society of Australasia (HERDSA) forming an important 
resource and outlet for publication. Librarians' links with academic development units are formed in different ways, including collaboration on learning initiatives or faculty development programs. Librarians have also begun to participate in, and complete, Graduate Certificates in Higher Education; courses which are usually organised and implemented by faculty developers.

In the 1990s librarians have been involved in a range of academic development initiatives. In Western Australia, checklists were created for unit coordinators, these were designed to encourage partnership between academics and librarians (Long, Pass and Radloff, 1994). The HERDSA Green Guide Developing students' library research skills (Bruce, 1992) captured examples of helping students learn using their information environment, and was the outcome of collaborations between librarians and faculty from a wide range of disciplines. At the Queensland University of Technology, sections of the Graduate Certificate in Higher Education were revised to model information literacy education and to raise faculty awareness of the need to foster students’ information capabilities (Bruce, Crebert and O’Leary, 1995). At the same institution, a document titled Developing Information Literate Graduates: Prompts for Good Practice (Bruce and Candy, 1995) was created, and has subsequently been extensively used in faculty development contexts. Workshops have been conducted to help faculty to consider the need for student information literacy, and to design learning opportunities accordingly, at several universities including Central Queensland University, Queensland University of Technology, University of Wollongong, University of Ballarat, and the University of Newcastle. Workshops such as these continue to be popular, often incorporating contributions from faculty. Most recently, the Australian Catholic University, on the recommendation of its information literacy committee, has commissioned day long workshops to be conducted on five of its campuses across Australia. These workshops aim to introduce faculty to the idea of information literacy education; and to help them design curriculum, including learning and assessment strategies, that encourage students to use the information practices expected of them outside formal learning situations.

\section{Conclusions}


In the literature reviewed for this article, there were examples of papers written for library-based conferences by faculty staff, papers jointly written by faculty and librarians for conferences and discipline journals, and papers written for the Lifelong Learning Conference. It has been evident that little of the literature is appearing in mainstream higher education journals or discipline-based journals, suggesting that the transformation of the information literacy agenda from a library-centred issue to a mainstream educational issue is only beginning.

Taken together, however, these examples of Australian higher education facultylibrary partnerships, reveal a substantial effort that is rarely considered as a whole. While many efforts still belong to single institutions, or units within those institutions, the cross system impact is potentially considerable. It is clearly time for Australian information literacy innovators to make a much stronger, and combined, stand about the nature and value of their work to the rest of the higher education community. The opportunity is available to systemically capture these elements, and to develop the synergies between them, as one of the fundamental keys to creating teaching-learning experiences that promote self-directed and critical lifelong learning.

\section{References}

Abbott, W. and Peach, D. (2000), “ Building info-skills by degrees; embedding information literacy in university study", Paper presented at the $21^{\text {st }}$ Annual Conference of the International Association of Technological University Libraries 3-7 July, Brisbane 2000.

Australian Catholic University Information Literacy Committee (1999), Information Literacy for Australian Catholic University, Report of the Australian Catholic University Information Literacy Committee, Chair: Craig Grimison. Unpublished Report.

Appleton, M. and Orr, D. (2000), “ Meeting the needs of distance education students”, in Bruce, C. and Candy, P. (Eds.) Information Literacy Around the World, Charles Sturt University Press, Riverina, pp. 11-24.

Appleton, K. McPherson, C. and Orr, D. (Eds.)(2000), Lifelong Learning Conference, Selected papers from the inaugural lifelong learning conference, Yeppoon, Queensland, Australia, 17-19 July 2000, Lifelong Learning Conference Committee.

Bailey, B. (1985), “Thesis practicum and the librarian’s role”, Journal of Academic Librarianship, Vol 11 No 2, pp. 79-81.

Biggs, J. (1999), Teaching for quality learning at university, Open University Press, Buckingham. 
Booker, D. (Ed.) (2000), Concept, Challenge, Conundrum: from library skills to information literacy. Proceedings of the Fourth National Information Literacy Conference, University of South Australia Library, Adelaide.

Bowden. J. and Marton, F. (1998), The University of Learning: beyond Quality and Competence, Kogan Page, London.

Bowden, J, Hart, G, King, B, Trigwell, K. Watts, O. (n.d) Generic Capabilities of ATN University Graduates. http://www.clt.uts.edu.au/ATN.grad.cap.project.index.html) Accessed September 2000.

Brewer, C. (2000), “ Integrating information literacy into the health science curriculum: longitudinal study of an information literacy program at the University of Wollongong”, in Di Booker (ed) ), Concept, Challenge, Conundrum: from library skills to information literacy. Proceedings of the Fourth National Information Literacy Conference, University of South Australia Library, Adelaide, pp. 66-75.

Bruce, C. (1990), "Information skills coursework for postgraduate students: investigation and response at the Queensland University of Technology”, Australian Academic and Research Libraries, Vol 21 No 4, pp. 224-232.

Bruce, C. (1992), Developing Students' Library Research Skills, Green Guide Number 13, Higher Education Development Society of Australasia, Campbelltown.

Bruce, C. (1994), "Research students' early experiences of the dissertation literature review”, Studies in Higher Education, Vol 19 No 2, pp. 217-229.

Bruce, C. (1997), Seven Faces of Information Literacy, AUSLIB Press, Adelaide.

Bruce, C. (in press) "Interpreting the scope of their literature review. Significant differences in research students' concerns.” New Library World

Bruce, C. and Candy P. (1995), "Developing information literate graduates: prompts for good practice”, in Booker, D. (Ed.) The Learning Link: Information Literacy In Practice, AUSLIB Press, South Australia, pp. 245-252.

Bruce, C. and Candy, P. (Eds) (2000a) Information Literacy Around the World: Advances in Programs and Research. Charles Sturt University Press, Riverina

Bruce, C. and Candy, P. (2000b), "Information literacy programs: people, politics and potential”, in Bruce, C. and Candy, P. (Eds.) Information Literacy Around the World: Advances in Programs and Research, Charles Sturt University Press, Riverina, pp. 1-10.

Bruce, C. Weeks, P. and Crebert, G. (1995), "Teaching lecturers, modelling information literacy education”, in The Learning Link: Information Literacy In Practice, in Booker, D. (Ed.) AUSLIB Press, South Australia, pp. 239-244.

Callan, P, Peacock, J, Poirier, J, Tweedale. R (in press) Practice makes information literacy perfect: models of educational collaboration at QUT. In Frylinck, J. (Ed.) ATN Professional Practice Publication No.2 Partners in Learning and Research, Curtin University, Perth.

Candy, P. (2000) "Mining in Cyberia: researching information literacy for the digital age”, in Bruce, C. and Candy, P. (Eds.) Information Literacy Around the World: Advances in Programs and Research, Charles Sturt University Press, Riverina, pp. 139-152. 
Candy, P. Crebert, G. and O’Leary, J. (1994), Developing Lifelong Learners Through Undergraduate Education. Commissioned Report No 28. National Board of Employment Education and Training, Australian Government Publishing Service, Canberra.

Catts, R. (2000), “Confirmation of phases in the relational model of information literacy”, in Appleton, K. McPherson, C. and Orr, D. (Eds.) Lifelong Learning Conference, Selected papers from the inaugural lifelong learning conference, Yeppoon, Queensland, Australia, 17-19 July 2000, Lifelong Learning Conference Committee, pp. 176-180.

Cunningham, S, Ryan, Y, Stedman, L, Tapsall, S, Bagdon, K, Flew, T, and Coaldrake, P. (2000), The Business of Borderless Education. Department of Education, Training and Youth Affairs, Australia.

Department of Education, Training and Youth Affairs. (2000), Staff 1999 Higher Education Statistics, Canberra, November 1999. DETYA No. 6409.HERC99A

Department of Education, Training and Youth Affairs. (2000), Students (Preliminary) 1999 Selected Higher Education Statistics, Canberra, August 1999. DETYA No. 6386.HERC99A

George, R. McClausand, H, Wache, D, and Doskatsch, I. (2000), “Information literacy: an institution wide strategy”, in Appleton, K. McPherson, C. and Orr, D. (Eds.) Lifelong Learning Conference, Selected papers from the inaugural lifelong learning conference, Yeppoon, Queensland, Australia, 17-19 July 2000, Lifelong Learning Conference Committee,pp. 181-187.

Hill, C. (2000), “Improving information skills programs using action-research”, in Booker, D. (Ed.) Concept, Challenge, Conundrum: from library skills to information literacy. Proceedings of the Fourth National Information Literacy Conference, University of South Australia Library, Adelaide, pp.139-146.

Hinton, L. (2000), “Students: “Where’s the library?” Lecturers: “databases huh?””, in Appleton, K. McPherson, C. and Orr, D. (Eds.) Lifelong Learning Conference, Selected papers from the inaugural lifelong learning conference, Yeppoon, Queensland, Australia, 17-19 July 2000, Lifelong Learning Conference Committee, pp. 188-193.

Long, J. Pass, G. and Radloff, A. (1994), “Academics and librarians; a vital partnership in quality teaching and learning”, in Summers, L. (Ed.) Quality in Teaching and Learning: making it happen, the proceedings of a teaching and learning forum. Curtin University, Perth.

Macauley, P. and Knight, S. (1998), A new model of library support for off-campus postgraduate research students, in Quality in postgraduate research: managing the new agenda. National Conference, Adelaide. 23-24 April 1998.

Macauley, P. (2000), "Pedagogic continuity in doctoral supervision: passing on or passing by information studies”, in Kiley, M. and Mullins, G. (Eds.) Quality in Postgraduate Research: Making Ends Meet, The Advisory Centre for University Education, University of Adelaide, pp. 215-225.

Milne, C. and Peisley, E. (2000), “Coming to terms with information literacies: developing a university wide introductory program”, in Appleton, K. McPherson, C. and Orr, D. (Eds.) Lifelong Learning Conference, Selected papers from the inaugural lifelong learning conference, 
Yeppoon, Queensland, Australia, 17-19 July 2000, Lifelong Learning Conference Committee, pp. 203-208.

Nimon, M. (2000), "Striking the right balance: information literacy and partnerships between librarian, lecturer and student”, in Booker, D. (Ed.) Concept, Challenge, Conundrum: from library skills to information literacy. Proceedings of the Fourth National Information Literacy Conference, University of South Australia Library, Adelaide, pp. 157-164.

Peacock, Judith (2000) Information literacy: Faculty/Library collaborative projects. Personal Communication. August 2000.

Radomski, N. (1999) Implementing information literacy: themes, issues and future directions, University of Ballarat, Ballarat.

Radomski, N. (2000), “Framing information literacy, the University of Ballarat experience”, in Bruce C. and Candy, P. (Eds) Information Literacy Around the World: Advances In Programs And Research, Charles Sturt University Press, Riverina, pp. 67-82.

Searl, K., Dwyer, T, Jirojwong, S, and Hinton, L. (2000), "Research and information literacy at CQU: an explanation of the attitudes of pre and post registration nursing students”, in Appleton, $\mathrm{K}$. McPherson, C. and Orr, D. (Eds.) Lifelong Learning Conference, Selected papers from the inaugural lifelong learning conference, Yeppoon, Queensland, Australia, 17-19 July 2000, Lifelong Learning Conference Committee, pp. 216-221.

Tinkler, D, Lepani, B and Mitchell, J. (1996) Education and Technology Convergence: a survey of Technological Infrastraucture in Education and the Professional Development and Support of Educators and Trainers in Information and Communication Technologies. Commissioned Report No.43 Australian Government Publishing Service, Canberra.

Turnbull, J, Frost, D,, and Croud, J. (2000), "Out of focus and into the frame, information skills benchmarking at the University of Queensland Library”, in Appleton, K, McPherson, C. and Orr, D. (Eds.) Lifelong Learning Conference, Selected papers from the inaugural lifelong learning conference, Yeppoon, Queensland, Australia, 17-19 July 2000, Lifelong Learning Conference Committee, pp. 222-227.

Wallace, M. C, Shorten, A, Crookes, P.A. (2000), "Teaching information literacy skills: An evaluation”, Nurse Education Today, Vol. 20., in press.

Wallace, M. C. Shorten, A. Crookes, P. A., McGurk, C. \& Brewer, C. (1999), "Integrating information literacies into an undergraduate nursing programme”, Nurse Education Today, Vol 19, pp. 136141.

Wright, L. and McGurk, C. (2000), "Integrating Information literacy: University of Wollongong experience”, in Bruce C. and Candy, P. (Eds) Information Literacy Around the World: Advances In Programs And Research, Charles Sturt University Press, Riverina, pp. 83-98.

\section{Acknowledgements}

Many people have made this paper possible. Camille McMahon conducted an initial literature search. Many colleagues from across Australia provided copies of papers 
and insights into programs, including Margaret Appleton, Chris Brewer, Judy Peacock, Craig Grimison, Catriona Mc Gurk, Lynne Wright, Natalie Radomski, and Irene Doskatch. I am also grateful to Hannelore Rader and Ilene Rockman for creating the opportunity to write the article.

${ }^{\mathrm{i}}$ Gateway to the homepages of Australian Universities is located at : http://www.detya.gov.au/highered/ausunis.htm 